\title{
Adolescent Health Development: A Relational Developmental Systems Perspective
}

\author{
Richard M. Lerner, Claire D. Brindis, \\ Milena Batanova, and Robert Wm. Blum
}

Consistent with the United Nations Conventions, adolescence encompasses the second decade of life (Lerner and Steinberg 2009). Since the emergence of the study of this portion of the life course (Hall 1904), adolescence has been regarded as a period characterized by purportedly troublesome transformations (e.g., in bodily attributes associated with puberty; Susman and Dorn 2009, 2013) and allegedly problematic transitions (e.g., in regard to socioemotional functions linked to self-definition or identity, Erikson 1959, or to changes in the focus of social

The original version of this chapter was revised.
An erratum to this chapter can be found at
https://doi.org/10.1007/978-3-319-47143-3_27

The writing of this chapter was supported in part by grants from the John Templeton Foundation. We are grateful to Elizabeth Goodman for her comments

R.M. Lerner, $\operatorname{PhD}(\bowtie)$

Tufts University, Medford, MA, USA

e-mail: Richard.lerner@tufts.edu

M. Batanova, PhD

Institute for Applied Research in Youth Development, Tufts University, Medford, MA, USA

C.D. Brindis, DrPH

University of California-San Francisco (UCSF), Philip R. Lee Institute for Health Policy Studies and the Adolescent and Young Adult Health National Resource Center, San Francisco, CA, USA

R.Wm. Blum, MD, MPH, PhD

Johns Hopkins Bloomberg School of Public Health, Baltimore, MD, USA relationships, from parents to peers, Freud 1969). When viewed from this "deficit" model, adolescents were seen by both scholars and the general public as both dangerous to themselves and to society (Anthony 1969). They were regarded as "problems to be managed" (Roth and BrooksGunn 2003a, b).

Certainly, it may be argued that adolescence is the most profound period of change within the life span. As in infancy and early to middle childhood, the individual's physiological, psychological, behavioral, and social relationship characteristics undergo both quantitative and qualitative changes, that is, transitions and transformations. For instance, changes in the prefrontal cortex, increases in the interconnectivity among brain regions, and increases in dopamine levels provide both vulnerabilities to risk and opportunities for growth in cognitive control (Steinberg 2010). At the same time, most youth in Western societies are experiencing great contextual changes, such as changing schools (e.g., Eccles 2004) and the increased relevance of peer influences on behavior (e.g., Gardner and Steinberg 2005). Moreover, in adolescence, the individual has the cognitive, behavioral, and social relational skills to contribute actively and often effectively to his or her own developmental changes (Lerner 1982; Lerner and BuschRossnagel 1981; Lerner and Walls 1999; Ricco and Overton 2011). In contrast to earlier developmental periods, adolescents have a burgeoning capacity 
for self-governance, for formulating and taking actions that exert at least some control over their own development. That is, there is uniquely marked development of intentional agency in adolescence. Agency involves self-regulatory skills that include, for instance, the selection of goals or the formulation of purposes that are of importance to adolescents' developing senses of self and growing attempts to find a means to "matter" in their world (Eccles 2004; Freund and Baltes 2002; Mascolo and Fischer 2015). There is also growth in the use of executive functioning, strategic thinking, and behavioral skills in recruiting goal-related resources that enable actions optimizing the chances of fulfilling their purposes. Furthermore, there is also development of the ability to compensate effectively when goals are blocked and/or to select new goals when initial optimization attempts fail and the chances of attaining an initial goal are lost (Gestsdottir and Lerner 2008; McClelland et al. 2015).

In general, scholars who study the adolescent period acknowledge that multiple dimensions of change involving the individual and his or her context characterize this portion of the life span (Lerner et al. 2015; Lerner and Steinberg 2009). However, substantial variation has emerged in scholars' approach to this individual-context relationship. Analogous to interpreting only main effects of statistical analyses framed by the General Linear Model, some scholars have focused on one domain of change (e.g., adolescent identity development) and have not emphasized other levels of organization within the ecology of human development (e.g., see Marcia 1980). Other scholars have taken a reductionist orientation to the phenomena of adolescence and have sought to use biogenic ideas (e.g., genetic or evolutionary biological ideas; see Bjorkland and Ellis, 2005) to interpret all psychological and social relationship phenomena of the period (see Elder 1980, 1998; Elder et al. 2015, for critiques of the main effect or reductionist approaches).

In turn, however, in 2003, Roth and BrooksGunn $(2003 a, b)$ reviewed the literature on youth development programs aimed at enhancing health and thriving among adolescents. They concluded that adolescents should be regarded not as problems to be managed but, instead, as resources to be developed. Their insight built on at least three sources. First, Larson (2000) provided a compelling vision for research aimed at emphasizing the strengths of adolescence (e.g., involving their burgeoning capacities for intentional selfregulation) and for using these strengths to promote positive youth development (PYD). Instead of health or positive development being conceptualized as the diminution or the absence of disease or of problem behaviors, respectively, the PYD perspective suggested that there were facets of thriving that, when promoted, resulted in healthy and positive development. Second, Eccles and Gootman (2002) edited a field-defining report issued by the National Academy of Sciences about the ways in which community programs for youth development could promote several attributes of psychological and behavioral functioning believed to be indicative of such development. The report included a summary of the attributes of positive development as involving constructs that could be summarized by "Five Cs:" competence, confidence, character, connection, and caring (see too, Lerner et al. 2005). Third, Hamilton (1999) explained that the idea of PYD was being used in the developmental science literature in three ways: (a) as a label for a model of the processes through which health and thriving developed in adolescence, (b) as a philosophy for or an approach to designing community-based programs aimed at promoting thriving, and (c) as instances of such programs.

The emphasis on strengths as compared to deficits and on links between the positive development of youth and their engagement with contextual resources or ecological "developmental assets" (Benson et al. 2006), represented by community-based youth development programs, reflected the spirit of the times (the zeitgeist) of developmental science during the latter years of the twentieth century and the first decade of the twenty-first century (Lerner 2012; Lerner et al. 2015). Conceptions of human development, which in earlier periods stressed genetic or maturational determinants of development or approaches to development that reduced human behavior to stimulus-response relations, were being replaced by ideas emphasizing that development involved mutually influential rela- 
tions among a person's biological and psychological characteristics, social relationships, and influences from families, schools, community institutions, out-of-school-time (OST) programs, and both the designed and natural environment.

Developmental scientists argued that all of these influences, although always present across life, change in their significance across both life and across historical periods (e.g., Bronfenbrenner and Morris 2006; Lerner 2012; Overton 2013, 2015). Indeed, we explain below that, today, these ideas have a new manifestation quite compatible with the PYD perspective: They are found in the seven principles of life course health development (see Halfon and Forrest 2017) that address the conceptualization of the nature and bases of health and positive behavior development across the life span.

Therefore, in the contemporary study of adolescent development, the main effect and reductionist approaches of the past are regarded as anachronistic ideas incapable of producing models that adequately account for the integration of multiple levels of organization within the ecology of human development (Lerner 2015; Lerner and Benson 2013a, b; Lerner et al. 2015). In particular, such traditional approaches overlook the burgeoning information indicating that this integration reflects systemic relations, that is, mutually influential patterns of covariation within and across these levels (e.g., see von Bertalanffy 1933, 1968). At this writing, then, models of adolescent development that are associated with what Overton has explained as a relational developmental systems (RDS) metatheory define the cutting edge of theory-predicated scholarship about adolescent development. This metatheory is derived from a process-relational paradigm (Overton 2015), and the concepts associated with RDS thinking are being used to describe, explain, and optimize the course of development in the second decade of life and, as such, to frame applied research aimed at promoting health and positive development among diverse adolescents (Lerner et al. 2015).

It is not coincidental that concepts associated with the RDS metatheory are entirely consistent with the seven life course health development principles proposed by Halfon and Forrest (2017). This congruence of ideas is based on a few common scholarly roots of these two sets of ideas for understanding human development. For example, the life course conceptions of Elder (1998; Elder et al. 2015), the life span developmental ideas of Baltes (e.g., 1997; Baltes et al. 2006), and the constructs associated with Bronfenbrenner's (1979, 2005; Bronfenbrenner and Morris 2006) bioecological model of human development have shaped both RDS thinking and the life course health development principles. It will be useful, then, to discuss the features of the RDS metatheory and, in this context, point to the compatibility between RDS concepts and the life course health development principles. This discussion will enable us to illustrate how the ideas associated with both approaches to adolescent development can innovatively integrate and extend scholarship about transitions and transformations characterizing the adolescent period. In addition, because of the emphasis in both sets of ideas on the concept of relative plasticity in human development-that is, on the potential for systematic changes in the structure and function of health assets across the life course-we will discuss how these two approaches afford optimism that relational changes linked to positive change in the health developmental system can be identified and used to promote thriving in adolescence.

\section{Viewing Adolescent Development Through the Lens of the Relational Developmental Systems Metatheory}

The study of human development, in general, and adolescent development, more specifically, has evolved from a field dominated by split, reductionist (psychogenic or biogenic) approaches to a multidisciplinary scholarly field (Lerner and Steinberg 2009), one that seeks to integrate variables from biological through cultural and historical levels of organization across the life span into a synthetic, coactional system (e.g., Elder 1998; Ford and Lerner 1992; Gottlieb 1997, 1998; Lerner 2012). Reductionist accounts 
of development that adhere to a Cartesian dualism pull apart (split) facets of the integrated developmental system (Overton 2015). For instance, reductionist views typically elevate the importance of such split formulations as nature versus nurture, continuity versus discontinuity, stability versus instability, or basic versus applied science (Lerner 2002, 2006).

Split approaches are rejected by proponents of theories derived from an RDS metatheory (e.g., Mistry and Wu 2010; Overton 2013; Overton and Lerner 2014), which in turn are derived from a process-relational paradigm (Overton 2015). Across the past four plus decades, several scholars have provided ideas contributing to the evolution of this paradigm (e.g., Baltes 1997; Baltes, et al., 2006; Brandtstädter 1998; Bronfenbrenner 1979, 2005; Bronfenbrenner and Morris 2006; Elder 1998; Elder et al. 2015; Ford and Lerner 1992; Nesselroade 1988; Overton 1973; Overton and Reese 1981; Riegel 1975, 1976; and, even earlier, see von Bertalanffy 1933).

Overton (e.g., 2013, 2015) has integrated and extended this scholarship. Overton explains that, compared to a Cartesian worldview, the processrelational paradigm focuses on process (systematic changes in the developmental system), becoming (moving from potential to actuality; a developmental process as having a past, present, and future; Whitehead 1929/1978), holism (the meanings of entities and events derive from the context in which they are embedded), relational analysis (assessment of the mutually influential relations within the developmental system), and the use of multiple perspectives and explanatory forms (employment of ideas from multiple theory-based models of change within and of the developmental system) in understanding human development. Within the process-relational paradigm, the organism is seen as inherently active, self-creating (autopoietic), self-organizing, selfregulating (agentic), nonlinear/complex, and adaptive (Overton 2015; see too Sokol et al. 2015). Similarly, these ideas are echoed in the life course health development principles (specifically, Nos. 1 and 3) that health development emerges as a consequence of complex, nonlinear process that results from person $\Leftrightarrow$ environment coactions that are multidimensional, multidirectional, and multilevel.

Accordingly, both within the RDS approach to theory and the life course health development principles, split conceptions are eschewed in favor of a metatheory that emphasizes the study and integration of different levels of organization, ranging from biology/physiology to culture and history, as a means to understand life span human development (Lerner 2006; Overton 2013, 2015), the production of health, and the development of disease. Accordingly, conceptual emphasis is placed on mutually influential relations between individuals and contexts, represented as individual $\Leftrightarrow$ context relations.

This representation of the coactions between person and setting within RDS-based models is not meant to convey a person-context interaction-which is typically represented in the developmental literature as person X context. An interaction connotes that the entities involved in the relation are separate and independent (as in a statistical interaction) and that, as such, their association involves a linear combination of discrete and separate variables. Both before and after the interaction, these entities (variables) are independent and unchanged by each other. The bidirectional arrow used in the RDS illustration of person $\Leftrightarrow$ context relations is intended to emphasize that the coaction of individual and context involves the entire developmental system. As such, the relations among levels of the autopoietic system, and not independent linear combinatorial attributes, are the focus in such a model. Indeed, the fusion of individual and context within the developmental system means that across ontogeny (across the life span), any portion of the system is inextricably embedded with-or embodied by, in Overton's (2013, 2015) conceptualization-all other portions of the developmental system. Embodiment refers to the way individuals behave, experience, and live in the world by being active agents with particular kinds of bodies; the body is integratively understood as a form (a biological referent), as lived experience (a psychological referent), and as an entity in active engagement with the world (a sociocultural referent) (Overton 2015). 
Similarly, within the life course health development perspective, health development is also embodied: It is an emergent property of living systems (Principle 1), and it develops continuously across the life span (Principle 2).

Within the context of such a bidirectional relational system, the embeddedness within history (temporality) is of fundamental significance (Elder 1998; Elder et al. 2015). We may note that the developmental system is embedded in history (temporality). This embeddedness means that change is constant in the developmental system and that, as such, there may be either stochastic or systematic changes in person $\Leftrightarrow$ context relations across time and place (Elder 1998; Elder et al. 2015; Misteli 2013). Sensitivity of change to time and place is also a key idea within the life course health development Principle 4, which states that health development is highly sensitive to the timing and social structure of environmental exposures. The presence of such temporality in individual $\Leftrightarrow$ context relations within the developmental system means that there always exists some potential for systematic change and, thus, for (relative) plasticity in human development. In short, potential plasticity in individual $\Leftrightarrow$ context relations derives from the "arrow of time" (Lerner 1984; Lerner and Benson 2013a, b; Overton 2013) running through the integrated (relational) developmental system.

\section{Three Moments of Analysis in an RDS Approach to Adolescent Health Development}

To elucidate the role of time and place in contributing to the bidirectional relations of focal concern within RDS metatheory, developmental scientists may focus on either the role of the individual or the context, in particular instantiations of individual $\Leftrightarrow$ context exchanges. This focus may seem contradictory to the fusion among levels of organization emphasized in this approach. However, as we noted earlier, Overton (2015) embeds the RDS metatheory in the process-relational paradigm (see, as well, Sokol et al. 2015). Overton uses this paradigm to explain the possibility of this changing focus in developmental analysis. He notes that the process-relational paradigm involves different moments within a research program.

One moment involves the idea of the identity of opposites, a second moment involves the opposites of identity, and a third (relationally integrative) moment involves the synthesis of wholes. In discussing these three moments of scientific analysis within RDS approaches to developmental science, we point to the predominant trait model of individuality, the Five-Factor Theory (FFT, involving the purported Big Five "personality traits" of conscientiousness, agreeableness, neuroticism, openness to experience, and extraversion; Costa and McCrae 1980, 2006; McCrae et al. 2000). The FFT example is a means to explain these RDS-based moments and to contrast their use with thinking associated with Cartesian, split, reductionist approaches to the study of the individual development.

The first moment recognizes that both individual and context define- and are mutually constituted by-each other in one moment, or point, in a program of developmental inquiry. Overton (2010, p. 14) notes that:
The principle of the identity of opposites estab- lishes the identity among parts of a whole by cast- ing them not as exclusive contradictions as in the split epistemology, but as differentiated polarities (i.e., coequals) of a unified (i.e., indissociable) inclusive matrix - as a relation. As differentia- tions, each pole defines and is defined by its opposite.

The identity of opposites, therefore, emphasizes the fused person $\Leftrightarrow$ context relationship as the primary unit of analysis for understanding development. As such, in this moment of research, developmental scientists would reject the idea that there are any aspects of human behavioral development- for instance, entities such as traits- that "are more or less immune to environmental influences" (McCrae et al. 2000, pp. 175); the idea that such entities are indicators of split notions reflecting "nature over nurture" (McCrae et al. 2000, p. 173) would also be rejected by developmental scientists working within this first moment of analysis.

The second moment that Overton (2010, 2013, 2015; Overton and Müller 2013) discusses is the opposites of identity. This moment allows 
one, in effect, to hold the other parts of the integrated system in abeyance and focus on one part of the system; however, the ultimate aim is one of reintegrating the part into the whole at a subsequent moment. Overton (2013, pp. 47-48) explains that:

The limitation of the identity moment of analysis is that, in establishing a flow of categories of one into the other, a stable base for inquiry that was provided by bedrock material atoms of the split metatheory is eliminated... Reestablishing a stable base-not an absolute fixity, nor an absolute relativity, but a relative relativity (Latour 1993) within relational metatheory requires moving to a second moment of analysis. In this moment of opposition, the law of contradiction is reasserted and categories again exclude each other. As a consequence of this exclusion, parts exhibit unique identities that differentiate each from the other.

Therefore, when functioning within this second moment of analysis, developmental scientists could focus solely on attributes of individuals, for instance, the purported traits of conscientiousness, agreeableness, neuroticism, openness to experience, and extraversion that comprise the Big Five components of the FFT (Costa and McCrae 1980, 2006; McCrae et al. 2000) and, for instance, study the psychometric properties of these constructs to provide "objective," or quantitative, indices of these attributes. Indeed, such psychometric work has often been a part of research programs framed by RDS models (e.g., Damon 2008; Lerner et al. 2015). Thus, working within this second moment of analysis, developmental scientists following an RDS-based model, and social or personality researchers using a Cartesian split model, would be engaging in commensurate work. However, the difference between these two groups of scholars is brought to the fore when the third moment of analysis discussed by Overton (2015) is considered.

The third moment, the synthesis of wholes, occurs when the first two moments are embedded in a multi-perspective process-relational paradigm and are recognized as mutually necessary in a systematic, integrative program of research, wherein one needs both of the first two moments. That is, "A complete relational program requires principles according to which the individual identity of each concept of a formerly dichotomous pair is maintained while simultaneously it is affirmed that each concept constitutes, and is constituted by the other" (Overton and Müller 2013, p. 35).

Accordingly, the developmental scientist working within an RDS model would use an "objective" measure studied within the second moment of analysis within an integrated, relational empirical approach that focused on the individual $\Leftrightarrow$ context relation. Clearly, the trait theorist would not take such a step, given that the work of such scholars is framed by the ideas, noted above, that context is irrelevant to the understanding (i.e., successful prediction) of the life course of the manifestation of traits. Indeed, in their belief "that personality traits are more or less immune to environmental influences" (McCrae et al. 2000, pp. 175), trait theorists maintain that contextual conditions, whether similar or not, are irrelevant to prediction; given the purported biological base of traits, only nature variables have predictive efficacy.

However, there is abundant evidence that purported traits are in fact not "trait-like" at all, that is, these attributes reflect relations between individuals and contexts, as they occur at particular times and places (Ardelt 2000; Block 1995, 2010; Elder 1998; Elder et al. 2015; Roberts et al. 2006). Indeed, methodological work framed by RDS concepts (e.g., Molenaar and Nesselroade 2014, 2015; Nesselroade 1988; Nesselroade and Molenaar 2010) indicates that the purported life span stability of traits, as well as the purported immunity to contextual influences, is empirically counterfactual. Moreover, underscoring the importance of this third moment of analysis discussed by Overton (2015), these methodological innovations demonstrate the ability to index with psychometric precision integrative individual $\Leftrightarrow$ context (including individual $\Leftrightarrow$ individual) units of analysis (e.g., Molenaar 2014; Molenaar et al. 2014; Molenaar and Nesselroade 2015). This innovation in developmental methodology is important for understanding key features of the individual $\Leftrightarrow$ context relational process propelling developmental change in adolescence. 


\section{Developmental Regulations, Adaptive Developmental Regulations, and Human Agency in RDS Metatheory}

Given the analytic moment of the identity of opposites - that each component of the developmental system constitutes, and is constituted by, the other components of the system-RDS metatheory focuses on the "rules" or processes which govern, or regulate, exchanges between individuals and their contexts. Such processes are the function of the developmental system. An RDS program of research might seek to understand the nature of relations between individuals and their contexts, including the dynamics of those relations across the life course. For instance, RDS-based research might ask how specific features of the individual and specific features of the context coalesce to influence the substantive course of individual $\Leftrightarrow$ individual relations.

Brandtstädter (1998) termed these bidirectional relations "developmental regulations" and noted that, when developmental regulations involve mutually beneficial individual $\Leftrightarrow$ context relations, then these developmental regulations are adaptive. Developmental regulations are the fundamental feature of human life, that is, all human life exists in a context and involves bidirectional exchanges with it (Darwin 1859; Forrest 2014; Tobach and Schneirla 1968). These exchanges involve physiological systems and functions (e.g., respiration, circulation, digestion, reproduction) and behaviors (e.g., social affiliation and cooperation, or aggression and competition, as might be involved in protection, hunting, and scavenging; Johanson and Edey 1981) and involve both organismic self-regulation (e.g., hypothalamic functioning, circadian rhythms) and intentional self-regulation (e.g., goal selection, resource recruitment, and executive functioning; Gestsdóttir and Lerner 2008).

Gestsdóttir et al. (2014) note that self-regulation is a multidimensional construct, involving a range of behaviors, from basic physiological functions to complex intentional cognitive processes (e.g., Bandura 2001; Brandtstädter 1998; McClelland et al. 2015). As such, self-regulation pertains to all aspects of adaption, as people alter their thoughts, attention, emotions, and behaviors to react to contextual events and, as well, to influence selected features of their contexts. Here, culture plays a key moderating role. Trommsdorff (2012) notes that self-regulation "is assumed to develop by organizing inner mental processes and behavior in line with cultural values, social expectations, internalized standards, and one's self-construal" (p. 19).

The developmental course of self-regulation is, in effect, the developmental course of human agency in the context of individual desires, purposes, needs, goals and identity, perceptions of and coactions with other people, the physical ecology, and culture (e.g., Damon 2008; Geldhof et al. 2010; Gestsdóttir and Lerner 2008; Lerner et al. 2001). Agency is a defining feature of the active, self-creating (autopoietic, enactive), and nonlinear adaptive living system (Overton and Lerner 2014; Narvaez 2008; Witherington 2014). Such agency is the individual's contribution to adaptive developmental regulations (Brandtstädter 1998, 1999).

The development of agency begins in early life, primarily with organismic self-regulation processes. However, as we have noted, by the time of adolescence, self-regulation is increasingly intentional and purposeful (Damon 2008) and involves the self-system and the phenomena associated with identity development (Gestsdóttir and Lerner 2008; Lerner et al. 2001). The adolescent instantiation of agency reflects ideas associated with the work of comparative psychologists Tobach and Schneirla (1968), who distinguished between the biosocial functioning of insects (e.g., ants) and the psychosocial functioning of organisms with higher psychological levels, levels that are marked by greater plasticity, rather than stereotypy, in their eventual highest levels of ontogenetic change. Such higher levels provide the physiological base for symbolic functioning.

In turn, reflecting the life course health development principles that evolution enables as well as constrains health development pathways and plasticity (Principle No. 5) and that optimal health development promotes survival, enhances thriving, and protects against disease (Principle No. 6), evolutionary biologists Jablonka and Lamb (2005) note that both psychological 
processes and cultural processes are integrated with the genetic and epigenetic processes of evolution to make human adaptiveness and contributions qualitatively different than corresponding instances of adaptiveness of social contributions among other organisms. Together, these comparative psychology and evolutionary biology literatures suggest that, among humans, adaptiveness and positive contributions reflect integrated cognitive, emotional, and behavioral processes that involve abstract, symbolic constructs, such as language or moral reasoning, or character virtues (e.g., Lerner and Callina 2014).

\section{Implications for Research About Adolescent Health Development}

Empirically, indexing such facets of adolescent health development, in general, or the complex dimensions of evolutionary change linked to adolescent health development more specifically (e.g., Gissis and Jablonka 2011; Lerner et al. 2015; Slavich and Cole 2013) may involve both point-in-time (cross-sectional) assessments and historical (longitudinal) assessments (Lerner 2004). Scientists must conduct such assessments within the context of recognizing that contexts are complex (e.g., they exist at multiple levels of organization; Bronfenbrenner 1979). Individuals cannot necessarily act in ways that benefit all levels and all components of the context at all times and places (Elder 1998). Thus, adaption is not treated as a categorical concept (as something that either exists or not) but, instead, as a multivariate concept comprised of ordinal or interval dimensions. Researchers studying adaptation would not ask, then, whether it exists or not; rather, the question would be how beneficial is the developmental regulation (the individual $\Leftrightarrow$ context relation) for specific people or specific social institutions of the context, at specific times and in specific places (e.g., see Bornstein 2006, 2017).

Consistent both with the seventh principle of life course health development, that is, that the cadence of human health development results from the synchronized timing of variables from all levels of the developmental systems - that is, molecular, physiological, behavioral, cultural, and evolutionary processes (e.g., Cole 2014; Meaney 2014; Slavich and Cole 2013) — and with the Bornstein (2017) "specificity principle," we suggest, therefore, that addressing a multipart "what" question is the key to conducting programmatic research about the function, structure, and content of health development in adolescence. In other words, to test RDS-based ideas about the ontogenetically changing structure of adolescent development in general and health development more specifically, researchers need to ascertain answers to the following multipart "what" questions:

1. What specific structure-content relations emerge; at

2. What specific levels of organization within the relational developmental system that are linked to;

3. What specific antecedent and consequent adaptive developmental regulations (to what trajectory of individual $\Leftrightarrow$ context relations); at

4. What specific points in adolescent development; for

5. What specific groups of youth; living in

6. What specific contexts; at

7. What specific points in time (history)?

Such work may have several benefits. Questions about coherence and reliability or consistency of indicators of health development with respect to variation in context may be especially useful for understanding the developmental course of multidimensional, latent variable conceptions of health among diverse adolescents. For instance, are specific indicators of, say, cardiovascular, respiratory, nutritional, or mental health manifested consistently across time and place? To what extent and for whom and under which conditions can biologic propensities to such health developmental challenges be moderated?

Consider nutrition more closely. How do adolescents' diets influence their cardio-metabolic risk as adolescents and adults? Do adolescents maintain a healthy diet across different settings involving peers and family members? Is there age-associated variation in answers to this question, for instance, variation associated with 
pubertal development or pubertal status/stage (e.g., early, on time, or late)? Do answers to these questions vary in relation to gender? As well, do they vary in relation to normative social transitions (e.g., moving from elementary school to middle school)? How do peer social networks influence these behaviors or family mealtime behaviors? Are answers moderated or changed by the socioeconomic, cultural, religious, or national contexts of youth? In turn, do answers here vary in relation to media exposure about eating and about desirable body types that may be prevalent for youth living in particular settings at particular times in history? Given the synchronization issues raised by the seventh life course health development principle, how are all these answers moderated or changed by what may be nonnormative life or historical events in the lives of adolescents (Baltes et al. 2006)? Examples here may be the death of a parent or deployment in the military (Cozza and Lerner 2013), family disruption due to divorce or separation, or family challenges in the face of environmental tragedies such as weather-related calamities or living in settings beset by violence.

The life course health development principles remind us that health development is highly sensitive to the timing and social structure of environmental events (Principle 4), and these examples of questions reflecting the specificity of health-related individual $\Leftrightarrow$ context relations that may impinge on the thriving of adolescents underscore the subtle and nuanced nature of the developmental system within which adolescent health development is embodied.

The idea of embodiment and of adolescent health development being an emergent property of the living system (Principle 1) underscores that it is insufficient to take a "main effect" approach to the study of even a facet of health development as complex as the effects of nutrition. Scientists and practitioners framing their research and applications, respectively, within RDS-based models and/or life course health development principles must also ask how do answers to all the questions we have posed regarding nutrition covary with comparable questions pertaining to adolescent lifestyle changes (e.g., involving sleep, exercise, or sexual debut), healthy status of bodily systems, and the presence of chronic and acute health challenges, of both more biological (e.g., hormonal changes) and more social origins (e.g., school bullying).

\section{Conclusions}

The interrelated "what" questions we have presented, illustrated by the example of nutrition's effects on health development, will, then, help developmental and medical science collaborate to understand the assuredly complex questions that need to be addressed in a scholarly agenda that comprehensively describes, explains, and optimizes the course of individual health development across the adolescent period. Developmental scientists know that in some senses each adolescent is like every other adolescent (e.g., there are nomothetic principles that apply to functioning of the physiological and psychological changes prototypic of the period), that each adolescent is like only some other adolescent (e.g., group differential variation exists as, for instance, when both the presence of good health status and healthy disparities vary across gender, race, socioeconomic level, culture, and nation of residence), and that each adolescent is like no other adolescent (e.g., there are idiographic characteristics pertinent to every young person, for instance, resulting from the relations among his/her timing of molecular, physiological, behavioral, cultural, and evolutionary processes brought into high relief by life course health development Principle 7). Therefore, the scholarly agenda brought to the fore by RDS metatheory and by the principles of life course health development will require scholars seeking to understand and to promote adolescent health to accept that their work will be exceedingly more complex than work predicated on main effect or reductionist approaches.

However, the relative plasticity in the development of human health and positive development that is found in studies that have been derived from or associated with RDS-based or life course health development-related scholarship, respectively (e.g., Lerner et al. 2015), is a basis 
for optimism that embracing such complexity is not only the intellectually correct path to take. It is also a feasible approach to adopt. The advances in relational developmental systems-predicated methods that we have discussed (e.g., Molenaar et al. 2014; Molenaar and Nesselroade 2014, 2015; Nesselroade and Molenaar 2010) provide powerful research and data analytic tools enabling such complexity to be integratively assessed.

The adolescent decade is "privileged" because of the generally disease-free status of individuals within it, as compared to subsequent decades of life (e.g., Susman and Dorn 2009; Paus 2009). Nevertheless, application of methods linked to the ideas of RDS metatheory and the principles of life course health development hold the promise of narrowing the disparities that exist across time and place in adolescent health development. In addition, therefore, these conceptions have one other vital asset; their use in research and application will enhance the probability that all youth will transition from adolescence into the adult years in manners that will enable their life course trajectories to more prominently be marked by health and thriving. Such a contribution by these conceptual frameworks will make quite vivid the insight of Lewin (1954) that there is nothing more practical than a good theory.

Acknowledgement Supported (in full or in part) by Grant \# U45MC27709 from the Department of Health and Human Services, Health Resources and Services Administration, Maternal and Child Health Bureau (Title V, Social Security Act), Division of Child, Adolescent and Family Health, Adolescent Health Branch.

\section{References}

Anthony, E. J. (1969). The reactions of adults to adolescents and their behavior. In G. Caplan \& S. Lebovici (Eds.), Adolescence: Psychosocial perspectives (p. 77). New York: Basic Books.

Ardelt, M. (2000). Still stable after all these years? Personality stability theory revisited. Social Psychology Quarterly, 63(4), 392-405.

Baltes, P. B. (1997). On the incomplete architecture of human ontogeny: Selection, optimization, and compensation as foundations of developmental theory. American Psychologist, 52, 366-380.

Baltes, P. B., Lindenberger, U., \& Staudinger, U. M. (2006). Lifespan theory in developmental psychology. In W. Damon \& R. M. Lerner (Eds.), Theoretical mod- els of human development. Vol. 1: Handbook of child psychology (6th ed., pp. 569-664). Hoboken: Wiley.

Bandura, A. (2001). Social cognitive theory: An agentic perspective. Annual Review of Psychology, 52 1-26. Palo Alto: Annual Reviews, Inc.

Benson, P. L., Scales, P. C., Hamilton, S. F., \& Semsa, A., Jr. (2006). Positive youth development: Theory, research, and applications. In R. M. Lerner (Ed.), Theoretical models of human development, Volume 1 of handbook of child psychology (6th ed., pp. 894-941). Editors-in-chief: W. Damon \& R. M. Lerner. Hoboken: Wiley.

Bjorklund, D. F., \& Ellis, B. J. (2005). Evolutionary psychology and child development: An emerging synthesis. In B. J. Ellis \& D. F. Bjorklund (Eds.), Origins of the social mind: Evolutionary psychology and child development (pp. 3-18). New York: Guilford.

Block, J. (1995). A contrarian view of the five-factor approach to personality description. Psychological Bulletin, 117, 187-215.

Block, J. (2010). The five-factor framing of personality and beyond: Some ruminations. Psychological Inquiry, 21(1), 2-25.

Bornstein, M. H. (2006). Parenting science and practice. In K. A. Renninger, \& I. E. Sigel (Vol. Eds.), Handbook of child psychology, Vol. 4: Child psychology in practice (6th ed., pp. 893-949). Editors-inChief: W. Damon, \& R. M. Lerner. Hoboken: Wiley.

Bornstein, M. H. (2017). The specificity principle in acculturation science. Perspectives on Psychological Science, 12(1), 3-45.

Brandtstädter, J. (1998). Action perspectives on human development. In R. M. Lerner (Ed.), Handbook of child psychology, Vol. 1 (5th ed., pp. 807-866). New York: Wiley.

Brandtstädter, J. (1999). The self in action and development: Cultural, biosocial, and ontogenetic bases of intentional self-development. In J. Brandtstädter \& R. M. Lerner (Eds.), Action and self-development: Theory and research through the life-span (pp. 37-65). Thousand Oaks: Sage.

Bronfenbrenner, U. (1979). The ecology of human development. Cambridge, MA: Harvard University Press.

Bronfenbrenner, U. (2005). Making human beings human. Thousand Oaks: Sage Publications.

Bronfenbrenner, U., \& Morris, P. A. (2006). The bioecological model of human development. In R. M. Lerner (Ed.), Theoretical models of human development. Volume 1 of Handbook of child psychology (6th ed., pp. 795-828). Editors-in-chief: W. Damon \& R. M. Lerner. Hoboken: Wiley.

Cole, S. W. (2014). Human social genomics. PLoS Genetics, 10(8), 1-7.

Costa, P. T., Jr., \& McCrae, R. R. (1980). Still stable after all these years: Personality as a key to some issues in adulthood and old age. In P. B. Baltes \& O. G. Brim Jr. (Eds.), Life span development and behavior (Vol. 3, pp. 65-102). New York: Academic Press.

Costa, P. T., Jr., \& McCrae, R. R. (2006). Age changes in personality and their origins: Comment on Roberts, 
Walton, and Viechtbauer (2006). Psychological Bulletin, 132, 28-30.

Cozza, S. J., \& Lerner, R. M. (Eds.). (2013). Military children and families. The Future of Children, 23(2), 3-11.

Damon, W. (2008). The path to purpose: Helping our children find their calling in life. New York: Simon and Schuster.

Darwin, C. (1859). The origin of species by means of natural selection or the preservation of favoured races in the struggle for life. London: J. Murray.

Eccles, J. S. (2004). Schools, academic motivation, and stage-environment fit. In R. M. Lerner \& L. Steinberg (Eds.), Handbook of adolescent psychology (2nd ed., pp. 125-153). Hoboken: Wiley.

Eccles, J. S., \& Gootman, J. A. (Eds.). (2002). Community programs to promote youth development/committee on community-level programs for youth. Washington, DC: National Academy Press.

Elder, G. H., Jr. (1980). Adolescence in historical perspective. In J. Adelson (Ed.), Handbook of adolescent psychology (pp. 3-46). New York: Wiley.

Elder, G. H., Jr. (1998). The life course and human development. In R. M. Lerner (Ed.), Handbook of child psychology, Volume 1: Theoretical models of human development (5th ed., pp. 939-991). Editor-in-chief: W. Damon. New York: Wiley.

Elder, G. H., Jr., Shanahan, M. J., \& Jennings, J. A. (2015). Human development in time and place. In M. H. Bornstein and T. Leventhal (Eds.), Handbook of child psychology and developmental science, Volume 4: Ecological settings and processes in developmental systems (7th ed., pp. 6-54). Editor-in-chief: R. M. Lerner. Hoboken: Wiley.

Ford, D. L., \& Lerner, R. M. (1992). Developmental systems theory: An integrative approach. Newbury Park: Sage.

Forrest, C. B. (2014). A living systems perspective on health. Medical Hypotheses, 82, 209-2143.

Freud, A. (1969). Adolescence as a developmental disturbance. In G. Caplan \& S. Lebovici (Eds.), Adolescence (pp. 5-10). New York: Basic Books.

Freund, A. M., \& Baltes, P. B. (2002). Life-management strategies of selection, optimization and compensation: Measurement by self-report and construct validity. Journal of Personality and Social Psychology, 82(4), 642-662.

Gardner, M., \& Steinberg, L. (2005). Peer influence on risk taking, risk preference, and risky decision making in adolescence and adulthood: An experimental study. Developmental Psychology, 41, 625-635.

Geldhof, G. J., Little, T. D., \& Colombo, J. (2010). Self-regulation across the lifespan. In M. E. Lamb \& A. M. Freund (Vol. Eds.), Social and emotional development. Volume 2 of the Handbook of lifespan development. Editor-in-Chief: R. M. Lerner. Hoboken: Wiley.

Gestsdóttir, G., \& Lerner, R. M. (2008). Positive development in adolescence: The development and role of intentional self regulation. Human Development, 51, 202-224.

Gestsdottir, S., Geldhof, G. J., Paus, T., Freund, A. M., Aðalbjarnardóttir, S., Lerner, J. V., \& Lerner, R. M.
(2014). Self-regulation among youth in four Western cultures: Is there an adolescence-specific structure of the Selection-Optimization-Compensation (SOC) model? International Journal of Behavioral Development, 39(4), 346-358.

Gissis, S. B., \& Jablonka, E. (Eds.). (2011). Transformations of Lamarchism: From subtle fluids to molecular biology. Cambridge, MA: The MIT Press.

Gottlieb, G. (1997). Synthesizing nature-nurture: Prenatal roots of instinctive behavior. Mahwah: Erlbaum.

Gottlieb, G. (1998). Normally occurring environmental and behavioral influences on gene activity: From central dogma to probabilistic epigenesis. Psychological Review, 105(4), 792-802.

Halfon, N., \& Forrest, C. B. (2017). The emerging theoretical framework of life course health development. In N. Halfon, C. B. Forrest, R. M. Lerner, \& E. Faustman (Eds.), Handbook of life course health-development science. Cham: Springer.

Hall, G. S. (1904). Adolescence: Its psychology and its relations to psychology. anthropology, sociology, sex, crime, religion, and education. New York: Appleton.

Hamilton, S. F. (1999). A three-part definition of youth development. Unpublished manuscript. Ithaca: Cornell University College of Human Ecology.

Jablonka, E., \& Lamb, M. J. (2005). Evolution in four dimensions: Genetic, epigenetic, behavioral, and symbolic variation in the history of life. Cambridge, MA: MIT Press.

Johanson, D. C., \& Edey, M. A. (1981). Lucy: The beginnings of humankind. New York: Simon \& Schuster.

Larson, R. W. (2000). Toward a psychology of positive youth development. American Psychologist, 55(1), 170-183.

Latour, B. (1993). We have never been modern (trans. Catherine Porter), Cambridge, MA: Harvard University Press.

Lerner, R. M., \& Busch-Rossnagel, N. A. (Eds.). (1981). Individuals as producers of their development: A lifespan perspective. New York: Academic Press.

Lerner, R. M. (1982). Children and adolescents as producers of their own development. Developmental Review, 2, 342-370.

Lerner, R. M. (1984). On the nature of human plasticity. New York: Cambridge University Press.

Lerner, R. M., \& Walls, T. (1999). Revisiting individuals as producers of their development: From dynamic interactionism to developmental systems. In J. Brandtstädter \& R. M. Lerner (Eds.), Action and selfdevelopment: Theory and research through the lifespan (pp. 3-36). Thousand Oaks: Sage.

Lerner, R. M. (2002). Concepts and theories of human development (3rd ed.). Mahwah: Lawrence Erlbaum Associates.

Lerner, R. M. (2004). Liberty: Thriving and civic engagement among America's youth. Thousand Oaks: Sage Publications.

Lerner, R. M., Lerner, J. V., Almerigi, J. B., Theokas, C., Phelps, E., Gestsdottir, S., et al. (2005). Positive Youth Development, Participation in community youth development programs, and community contribu- 
tions of fifthgrade adolescents: Findings from the first wave of the 4-H study of Positive Youth Development. Journal of Early Adolescence, 25(1), 17-71.

Lerner, R. M. (Ed.). (2006). Theoretical models of human development. Volume 1 of Handbook of child psychology (6th ed.). Editors-in-chief: W. Damon \& R. M. Lerner. Hoboken: Wiley.

Lerner, R. M. (2012). Essay review: Developmental science: Past, present, and future. International Journal of Developmental Science, 6(1-2), 29-36.

Lerner, R. M., \& Callina, K. S. (2014). The study of character development: Towards tests of a relational developmental systems model. Human Development, 57(6), 322-346.

Lerner, R. M. (Editor-in-Chief). (2015). Handbook of child psychology and developmental science (7th ed.). Hoboken: Wiley.

Lerner, R. M., \& Benson, J. B. (Eds.). (2013a). Embodiment and epigenesis: Theoretical and methodological issues in understanding the role of biology within the relational developmental system. Volume 1: Philosophical, theoretical, and biological dimensions. advances in child development and behavior (Vol. 44). London: Elsevier.

Lerner, R. M., \& Benson, J. B. (Eds.). (2013b). Embodiment and epigenesis: Theoretical and methodological issues in understanding the role of biology within the relational developmental system. Volume 2: Ontogenetic dimensions. Advances in child development and behavior (Vol. 45). London: Elsevier.

Lerner, R. M., \& Callina, K. S. (2015). The study of character development: Towards tests of a relational developmental systems model. Human Development, 57(6), 322-346.

Lerner, R. M., \& Steinberg, L. (2009). The scientific study of adolescent development. In R. M. Lerner \& L. Steinberg (Eds.), Handbook of adolescent psychology (3rd ed., pp. 3-14). Hoboken: Wiley.

Lerner, R. M., Freund, A. M., De Stefanis, I., \& Habermas, T. (2001). Understanding developmental regulation in adolescence: The use of the selection, optimization, and compensation model. Human Development, 44, 29-50.

Lerner, R. M., Lerner, J. V., Bowers, E., \& Geldhof, G. J. (2015). Positive youth development: A relational developmental systems model. In W. F. Overton \& P. C. Molenaar (Eds.), Theory and method. Volume 1 of the Handbook of child psychology and developmental science (7th ed., pp. 607-651). Editor-in-chief: R. M. Lerner. Hoboken: Wiley.

Lewin, K. (1954). Behavior and development as a function of the total situation. In L. Carmichael (Ed.), Manual of child psychology (2nd ed.). New York: Wiley.

Marcia, J. E. (1980). Identity in adolescence. In J. Adelson (Ed.), Handbook of adolescent psychology (pp. 159187). New York: Wiley.

Mascalo, M. F., \& Fischer, K. W. (2015). The dynamic development of thinking, feeling, and acting: Infancy through adulthood In W. F. Overton \& P. C. M. Molenaar (Eds.), Handbook of child psychology and developmental science (7th ed.), Volume 1: Theory and method. Editor-in-chief: R. M. Lerner. Hoboken: Wiley.
McClelland, M. M., Geldhof, G. J., Cameron, C. E., \& Wanless, S. B. (2015). Development and selfregulation. In W. F. Overton \& P. C. Molenaar (Eds.), Theory and method. Volume 1 of the Handbook of child psychology and developmental science (7th ed.). Editor-in-chief: R. M. Lerner. Hoboken: Wiley.

McCrae, R. R., Costa, P. T., Hrebickova, M., Ostendord, F., Angleitner, A., \& Avia, M. D. (2000). Nature over nurture: Temperament, personality, and life span development. Journal of Personality and Social Psychology, 78(1), 173-186.

Meaney, M. (2014, October 10). Epigenetics offer hope for disadvantaged children. [Children and family: Blog]. Retrieved from http://childandfamilyblog.com/ epigenetics-offer-hope-disadvantaged-children/

Misteli, T. (2013). The cell biology of genomes: Bringing the double helix to life. Cell, 152(6), 1209-1212.

Mistry, J., \& Wu, J. (2010). Navigating cultural worlds and negotiating identities: A conceptual model. Human Development, 53(1), 5-25.

Molenaar, P. C. (2014). Dynamic models of biological pattern formation have surprising implications for understanding the epigenetics of development. Research in Human Development, 11(1), 50-62.

Molenaar, P. C., \& Nesselroade, J. R. (2014). New trends in the inductive use of relation developmental systems theory: Ergodicity, nonstationarity, and heterogeneity. In P. C. Molenaar, R. M. Lerner, \& K. M. Newell (Eds.), Handbook of developmental systems and methodology (pp. 442-462). New York: Guilford Press.

Molenaar, P. C. M., \& Nesselroade, J. R. (2015). Systems methods for developmental research. In W. F. Overton \& P. C. M. Molenaar (Eds.), Handbook of child psychology and developmental science (7th ed.), Volume 1: Theory and method. Editor-in-chief: R. M. Lerner. Hoboken: Wiley.

Molenaar, P. C., Lerner, R. M., \& Newell, K. M. (2014). Developmental systems theory and methodology: A review of the issues. In P. C. Molenaar, R. M. Lerner, \& K. M. Newell (Eds.), Handbook of developmental systems and methodology (pp. 3-18). New York: Guilford Press.

Narvaez, D. (2008). Human flourishing and moral development: Cognitive and neurobiological perspectives of virtue development. In L. Nucci \& D. Narvaez (Eds.), Handbook of moral and character education (pp. 310-327). Oxford: Routledge.

Nesselroade, J. R. (1988). Some implications of the traitstate distinction for the study of development over the life-span: The case of personality. In P. B. Baltes, D. L. Featherman, \& R. M. Lerner (Eds.), Life-span development and behavior (Vol. 8, pp. 163-189). Hillsdale: Erlbaum.

Nesselroade, J. R., \& Molenaar, P. C. M. (2010). Emphasizing intraindividual variability in the study of development over the life span. In W. F. Overton (Ed.), The handbook of life-span development. Vol. 1: Cognition, biology, methods (pp. 30-54). Editor-inchief: R. M. Lerner. Hoboken: Wiley.

Overton, W. F. (1973). On the assumptive base of the nature-nurture controversy: Additive versus interactive conceptions. Human Development, 16, 74-89. 
Overton, W. F. (2010). Life-span development: Concepts and issues. In W. F. Overton (Ed), Cognition, biology, and methods across the lifespan. Handbook of life-span development. (Vol. 1, pp. 1-29). Editor-in-chief: R. M. Lerner. Hoboken: Wiley.

Overton, W. F. (2013). Relationism and relational developmental systems; A paradigm for developmental science in the post-Cartesian era. In R. M. Lerner and J. B. Benson (Eds.), Advances in child development and behavior, volume 44: Embodiment and epigenesis: Theoretical and methodological issues in understanding the role of biology within the relational developmental system, Part A: Philosophical, theoretical, and biological dimensions (pp. 24-64). London: Elsevier. Development of Character 49.

Overton, W. F. (2015). Process and relational developmental systems. In W. F. Overton \& P. C. Molenaar (Eds.), Theory and method. Volume 1 of the Handbook of child psychology and developmental science (7th ed., pp. 9-62). Editor-in-chief: R. M. Lerner. Hoboken: Wiley.

Overton, W. F., \& Lerner, R. M. (2014). Fundamental concepts and methods in developmental science: A relational perspective. Research in Human Development, 11(1), 63-73.

Overton, W. F., \& Mueller, U. (2013). Meta-theories, theories, and concepts in the study of development. In R. M. Lerner, M A. Easterbrooks, \& J. Mistry (Eds.), Comprehensive handbook of psychology: developmental psychology: Vol. 6. (pp. 19-58). Editorin-Chief: Irving B. Weiner. New York: Wiley.

Overton, W. F., \& Reese, H. W. (1981). Conceptual prerequisites for an understanding of stability-change and continuity-discontinuity. International Journal of Behavioral Development, 4, 99-123.

Paus, T. (2009). Brain development. In R. M. Lerner \& L. Steinberg (Eds.), Handbook of adolescent psychology (3rd ed., pp. 95-115).

Ricco, R., \& Overton, W. F. (2011). Dual systems competence $B$-à procedural processing: A relational developmental systems approach to reasoning. Developmental Review, 31, 119-150. http://dx.doi.org/10.1016/j. dr.2011.07.005.

Riegel, K. F. (1975). Toward a dialectical theory of human development. Human Development, 18, 50-64.

Riegel, K. F. (1976). The dialectics of human development. American Psychologist, 31, 689-700.

Roberts, B. W., Walton, K. E., \& Viechtbauer, W. (2006). Patterns of mean-level change in personality traits across the life course: A meta-analysis of longitudinal studies. Psychological Bulletin, 132(1), 1-25.
Roth, J. L., \& Brooks-Gunn, J. (2003a). What is a youth development program? Identification and defining principles. In F. Jacobs, D. Wertlieb, \& R. M. Lerner (Eds.), Enhancing the life chances of youth and families: Public service systems and public policy perspectives: Vol. 2 handbook of applied developmental science: Promoting positive child, adolescent, and family development through research, policies, and programs (pp. 197-223). Thousand Oaks: Sage.

Roth, J. L., \& Brooks-Gunn, J. (2003b). What exactly is a youth development program? Answers from research and practice. Applied Developmental Science, 7, 94-111.

Slavich, G. M., \& Cole, S. W. (2013). The emerging field of human social genomics. Clinical Psychological Science, 1, 331-348.

Sokol, B. W., Hammond, S., Kuebli, J., \& Sweetman, L. (2015). The development of agency. In W. F. Overton \& P. C. Molenaar (Eds.,) Theory and method. Volume 1 of development of the Handbook of child psychology and developmental science (7th ed.). Editor-in-chief: R. M. Lerner. Hoboken: Wiley.

Steinberg, L. (2010). A dual systems models of adolescent risk-taking. Developmental Psychobiology, 52, 216-224.

Susman, E., \& Dorn, L. D. (2009). Puberty: Its role in development. In R. M. Lerner \& L. Steinberg (Eds.), Handbook of adolescent psychology (3rd ed., pp. 116151). Hoboken: Wiley.

Susman, E. J., \& Dorn, L. D. (2013). Puberty: Its role in development. In R. M. Lerner, M. A., Easterbrooks, \& J. Mistry (Eds.), Handbook of psychology, Volume 6: Developmental psychology (2nd ed., pp. 289-320). Editor-inchief: I. B. Weiner. Hoboken: Wiley.

Tobach, E., \& Schneirla, T. C. (1968). The biopsychology of social behavior of animals. In R. E. Cooke \& S. Levin (Eds.), Biologic basis of pediatric practice (pp. 68-82). New York: McGraw-Hill.

Trommsdorff, G. (2012). Development of "agentic" regulation in cultural context: The role of self and world views. Child Development Perspectives, 6(1), 19-26.

von Bertalanffy, L. (1933). Modern theories of development. London: Oxford University Press.

von Bertalanffy, L. (1968). General systems theory. New York: Braziller.

Whitehead, A. N. (1929/1978). Process and reality. Corrected edn. New York: The Free

Witherington, D. C. (2014). Self-organization and explanatory pluralism: Avoiding the snares of reductionism in developmental science. Research In Human Development, 11, 22-36.

Open Access This chapter is licensed under the terms of the Creative Commons Attribution 4.0 International License (http://creativecommons.org/licenses/by/4.0/), which permits use, sharing, adaptation, distribution and reproduction in any medium or format, as long as you give appropriate credit to the original author(s) and the source, provide a link to the Creative Commons license and indicate if changes were made.

The images or other third party material in this chapter are included in the chapter's Creative Commons license, unless indicated otherwise in a credit line to the material. If material is not included in the chapter's Creative Commons license and your intended use is not permitted by statutory regulation or exceeds the permitted use, you will need to obtain permission directly from the copyright holder. 